\title{
Athlete Endorsements Effect on Equipment Sales
}

\author{
Kathan Gandhi ${ }^{\# 1}$, Mrs. Kacie Smith ${ }^{\# 2}$ \\ \#1 9607 Custer Road, (469) 605-7647, kathanpgandhi@gmail.com \\ \#2 (469) 633-5800 smithkac@ friscoisd.org
}

\section{ABSTRACT}

The study was aimed to find a relation between sports equipment sales change for sports brands and endorsements by focusing on number of endorsements, endorser ratings, total marketing costs, and number of stores from 2013 to 2017. The sample consisted of Nike, Adidas, Under Armour, Dick's Sporting Goods, and Amer Sports. The top 10 sports in the world were determined to limit the scope of endorsers focused on for sports brands. Regression was used to find relationships between the factors. The paper proved that more number of endorsements has no influence on the change of equipment sales and there seemed to be a trend for better equipment sales if the endorser rating and total marketing costs were above average.

\section{INTRODUCTION}

\subsection{Overview}

According to the Council of Europe, sports is any "form of physical activity" for "well-being, ... bonding or ... competition." Historically, sports originated in Greece as "the ancient Olympic Games ... in 776 B.C.E ${ }^{[]]}$." Since then, it has faced many conflicts including the preference for team sports or individual sports, ownership of sports businesses, drugs, and use of high-tech equipment.

The prominence of sports has led to the establishment of a big industry. Various Ph.D. professors at Nove de Julho University and Federal University of Sao Paulo say that sports has eventually gained a firm hold as an industry, with athletes starting their own ventures or representing different brands. Brands are seen as popular companies, but they really are companies that "differentiat[e] [themselves] from others" and gain a "competitive advantage," through advertisements or social media announcements ${ }^{[\mathrm{II}]}$. Marc Peyser, ${ }^{[\mathrm{III}]} \mathrm{a}$ credible journalist who worked with Penguin Random House and Reader's Digest, and others believe that the valuation of the sporting industry has fluctuated, but it remains a very big industry and [was] "a \$12.6 billion industry," back in 1999.

Sporting brand products have risen in popularity with the surge in popularity of sports. Sporting goods are fashionable and an emerging norm recently ${ }^{[\mathrm{V}]}$. Merchandise of popular teams became a collection that produced great profit margins ${ }^{[\mathrm{V}]}$. Jason W. Lee, PhD, Professor of Sport Management at the University of North Florida and Patrick W. Kraft, ${ }^{[\mathrm{VI}]}$ Athletics Director at Temple University provide important information. Sports brands have a big market but they face tough competition in the highly valued sports industry. The industry's very own celebrities have helped these companies sell products and promote the brands through celebrity endorsements. According to Gerritsen\& van Rheenen, ${ }^{[\mathrm{VII}]}$ economics professors at Utrecht University and Erasmus School of Economics respectively, a celebrity endorsement is an "agreement" between a celebrity and an entity "to use the celebrity for the purpose of promoting the entity."

These endorsements have been used as effective marketing strategies since a long time. Famous athlete endorsements can be traced back to "the 1930s, [where] Babe Ruth was 
one of the first [endorsers] for Red Rock Cola" [VIII]. Gradually, the athlete endorsement business grew and boomed in the latter half of the 20th century. In changing times, advertisers became more open-minded and innovative leading to the "domina[nce]" of endorsements "by black athletes",[III].

\subsection{Literature Review}

"Endorsements [we]re a big part of" sports business ${ }^{[I I]}$. Globally, between 25 to $30 \%$ of advertisements featured celebrity endorsements ${ }^{[\mathrm{II}]}$. Gheorghe H. Popescu, ${ }^{[\mathrm{IX}]}$ professor at DimitrieCantemir Christian University, argues that the underlying "hope [of endorsements is] that a celebrity's possible success will be shifted to the firm's name". The global assumption of this method is that the firm will be able to reap larger rewards, such as increased sales and use of the athlete's image, from a commitment to an athlete ${ }^{[\mathrm{X}]}$.

The science of celebrity endorsements is rooted in the human brain. Homo sapiens associate with those they knew as it was necessary for survival ${ }^{[\mathrm{VIII}]}$. So, when a familiar face promotes a product, it seems as if the product itself is familiar, which makes customers more likely to buy it ${ }^{[\mathrm{VIII}]}$. It enables the "transfer of [traits] of the celebrity to the brand," transforming the brand image accordingly ${ }^{[I I]}$.

Brands should make "advertisements [more] 'believab[le]' to develop congruence and relate with their audience well ${ }^{[\mathrm{IX}]}$. Marketers need versatile ideas to "reach their target market effectively," during times of increased advertising ${ }^{[\mathrm{XI}]}$. They need to "convey ...that ...purchasing [their] product," will satisfy people's aims ${ }^{[I]}$. Such marketing methods appeal to reasoning and may evoke brand loyalty from customers. For a sports corporation, brand loyalty from all its customers is the desired outcome. Loyalty is vital for any company to sell and saves considerable amounts of money from the brand's marketing budget ${ }^{[\mathrm{V}]}$. There are mainly six factors that influence brand loyalty: brand name, product quality, price, promotion, service quality, and store environment ${ }^{[\mathrm{IV}]}$. Economically, athlete endorsements are a sensible investment to gain an advantage in the sports industry. The utilization of celebrities in advertisements can produce a competitive benefit by differentiating a company's product from rivals ${ }^{[\mathrm{IX}]}$.

Due to grander marketing by competitors, new companies struggled and had to implement new methods to emerge. For example, Under Armour implemented innovative means like word of mouth publicity. They aligned with current trends and promoted themselves through non-traditional means like video ${ }^{[\mathrm{VI}]}$. Other young companies developed similar strategies to market themselves better.

However, there are potential repercussions. Plausible risks of endorsements include the celebrity overshadowing the brand itself, the brand needing defense against "public polemic," and losing acceptance among people ${ }^{[\mathrm{XX}]}$. Hence, to maximize the gains of athlete endorsements and convey the message effectively, the endorsement celebrity must align closely with the brand and its characteristics. In fact, this aspect is defined as congruence, a match in a "set of attributes that makes ...the celebrity ...fit" for the endorsement ${ }^{[I]}$. There are several factors that help in determining the congruence of a brand with its endorser: categorization of the product, endorser credibility, and endorser attractiveness ${ }^{[\mathrm{IX}]}$. Koo et al. ${ }^{[\mathrm{XX}]}$ think "perceived attractiveness, trustworthiness, and expertise" are the "primary characteristics in defining ... source credibility."

Moreover, many criticized endorsements when the form of advertising seemed to be stagnating in performance. "Some athletes and spectators resentfully accuse[d] the media" ${ }^{\text {XXII] }}$. Horovitz ${ }^{[\mathrm{XXIII}]}$ relied on two surveys to indicate that celebrities weren't as influential as they used to be. Similarly, Kirby ${ }^{[\mathrm{XXIV}]}$ mentions a survey where, $56 \%$ of students were influenced by peers, while only $20 \%$ were affected by a celebrity in making their purchasing decision. These rising concerns made brands hire firms that analyze and rate 
celebrities on their 'likeability' and influence on purchasing decisions ${ }^{[\mathrm{XV}]}$. Still, several companies continued using famous athletes. The commonly held belief in the late 1990's was that the era of athlete endorsements had come to a close. Fashion was changing at that time, and the larger entertainment industry was looked at more to find endorsers ${ }^{[\mathrm{III}]}$.

Another emerging concern was the possible repercussions of negative endorser behavior or performance. Tiger Woods was alleged to have affairs with various women. So, he took time away from the game in order to resolve his family issues. Due to this conflict, he gathered public criticism and impacted the brands he endorsed ${ }^{[\mathrm{XV}]}$. To protect themselves against endorser criticism and resulting economic loss, brands pursued athlete endorsement insurance. The insurance was calculated based on additional revenue that the endorser brought to the company in normal ${ }^{[\mathrm{XVI}]}$. Soon, the demand for endorsement insurance increased.

Upadhyay's work $^{[\mathrm{XVII}]}$ demonstrated that poor performance of sports athletes and their teams deteriorates public support. Hence, it is important to ensure that the chosen endorser keeps doing well in everyone's eyes. If an endorser gets questioned, companies usually terminate their sponsorship, as seen in Cristiano Ronaldo's contract with EA when there were rape allegations against him. Sometimes, a brand accepts the blame and stands by its important endorsers.

Despite difficulties in producing better results for companies, the endorsements have continued to rise in value and number. Michael Jordan, Roger Federer, Virat Kohli, Tiger Woods, and Usain Bolt are just some of the names that have featured in multiple advertisements for highly valued companies.

It is important to understand the endorser effects have on the brands represented. The brands need to understand well the areas that endorsers influence and try to work out strategies to maximize benefits from their cherished athletes. Three economics professors at Tepper School of Business believe it is difficult to "identify the endorsement ["s] effect" on the brand's performance as there are "other confounding" variables that contribute to the same outcome ${ }^{[\mathrm{XVIII}]}$. How an endorser's effectiveness should be measured is heavily debated, but the majority usually prefers a comparison to company value, sales, or stock price as an explanation. Commonly, the company sees a boost in sales around an endorser's accomplishment of a major achievement ${ }^{[\mathrm{VII}]}$. But, there is also a chance to see some harm to their sales and reputation if an endorser ends up in a crisis ${ }^{[\mathrm{XV}]}$. As attention for winning teams was seen to be lower than individuals, I will focus on how individual athletes and what effect their endorsements have on equipment sales change of a sports brand ${ }^{[\mathrm{VII}]}$. Gerritsen\& van Rheenen ${ }^{[\mathrm{VII}]}$ have found that clothing brands are more visible and have a clear correlation with the sponsored athlete's achievement, but the question of equipment remains unclear. There isn't much evidence in order to consolidate its significance either ${ }^{[\mathrm{VII}]}$. Conversely, the athletes usually promote equipment or shoes in marketing efforts for sports brands rather than their clothing. Some have even achieved high status with their own subset brand within the company - Nike owns both Air Jordan, a basketball shoe brand based on Michael Jordan and $\mathrm{RF}$, a tennis brand taken over from Roger Federer.

In fact, a comprehensive study that compared endorser's performance on the field to the brand's sales and stock market price found that results for "endorsed equipment brands after the end of a tournament" were insignificant ${ }^{[\mathrm{VII}]}$. Between sales and stock market price, Elberse and Verleun ${ }^{[\mathrm{XIX}]}$ (economists at Harvard Business School and Barclays Capital) prefer sales as an indicator of an endorser's effectiveness as it is "more relevant for marketing and comparison to the competition". However, Gerritsen and van Rheenen ${ }^{[\mathrm{VII}]}$ call them into question by stating that the factors which "determined their findings" are "unclear." In order to explain the connection between sports endorsements and brand equipment sales, I will 
attempt to clearly find a relationship between sports brands equipment sales change and specific factors of athlete endorsements during 2013-2017.

I will try to answer: How have the number of athlete endorsements, the appeal of the athlete endorsers, and the total marketing costs for the endorsements in Nike's marketing impacted the company's equipment sales from 2013 to 2017 ?

Assuming top 10 sports athletes are prominent in brand endorsements for featured equipment, I believe:

1. Although current relationship between athlete endorsements and their effect on equipment sales is ambiguous, ${ }^{[7]}$ a brand's athlete endorsements should contribute to higher equipment sales.

2. The change in equipment sales across the years 2013-2017 is impacted by number of endorsements, the effectiveness of the athlete endorsers chosen by the brand, and the total marketing costs for the endorsements.

\section{METHODOLOGY}

The method used is non-experimental so only correlations can be found, which can allow us to see how equipment revenue changes based on endorsement factors.

Inspired by Gerritsen\& van Rheenen's ${ }^{[\mathrm{VII}]}$ methodology, I decided to account for various variables and focus on certain sports in order to develop my correlation results and compare the impact on endorsement equipment sales. Instead of 3 sports, I decided to focus on ten and pick them with a process. I also used their reasoning in developing regression and focusing on pertinent factors. I agreed with some of their choices such as world rankings and winning tournaments, but not with separately adjusting for most endorsed brand in a particular sport. I believed it was a maneuver to increase chances of getting an expected result and thus, created bias.

\subsection{Sport Selection}

Initially, we must determine what sports we are focusing on and why they should be chosen. Martin J. H. ${ }^{[\mathrm{XX}]}$ has shown that the sport that a brand endorser plays is very important to consider if they endorse non-sport products. I believe it is important for endorsing sports products too. The two major parameters I am using to determine the importance of sports are: viewership worldwide through all modes of communication and the number of athletes from each sport that are in the top 100 earners, according to Forbes. The viewership helps explain the popularity of the sport and the number of top 100 earning athletes helps explain how highly the sport is funded and valued by businesses. The top 100 earners list should be highly accurate, but it is coming from asingular source. On the other hand, the viewership worldwide is mostly estimated but can be acquired from multiple sources. I will create two ranking lists for the two parameters and choose the top 5 sports in the lists. If there are repeats, they will not be counted towards the 10 sports I will select to focus on.

Then, I will be using 4 sports equipment brands who have a significant market share in the sports industry, the ratio between the company's value and the market value $(>0.5 \%)$, Nike being my 5 th one, to represent the population of popular sports equipment companies. The 4 sports equipment brands I am choosing are - Adidas, Dick's Sporting Goods, Amer Sports, Under Armour. I have chosen this sample because only key large-scale companies in the sports equipment market will have enough resources to hire athlete endorsers and produce quality advertising campaigns to increase their customer base, like Nike.

\subsection{Endorser Factor}

As the sample companies have been selected, we will move on to addressing the endorser aspect of my methodology. The most direct and readily available measure of sales is total revenue of a company as it measures how much money the company was able to 
produce by selling its products. However, profit is the main motive for companies. Profit only composes a part of the total revenue, but it is harder to determine as companies avoid sharing profits.

Based on the format of the results and analysis technique used by Dupee et. al, ${ }^{[\mathrm{XI}]} \mathrm{I}$ will be using the correlation technique to try and explain possible causes of the fluctuation in equipment sales. I also used one of their parameters - world ranking - by incorporating it in the weighted athlete measure, which shall be explained later.

\section{Variables}

As I am focusing on the company's equipment sales, I will gather the sales earned from equipment of the 5 companies for the last 5 years. Based on these values, I will find percentage differences from last year and make this percentage my fixed y-axis variable. [See Table 3]

Next, I will have to find the different $\mathrm{x}$-axis variables which I can compare with the revenue changes to determine what kind of an impact endorsements have on the brand's equipment sales.

I will try to establish the number of endorsements that were conducted by the brand in the selected sports in the years (2013-2017). This data will be collected from databases or company reports. If, they aren't found, the whole company will be removed from consideration for this variable. The quantity of endorsements will be needed to understand if the sheer magnitude of advertising can boost sales.

For the same time period, I will also find a weighted measure of the endorsers' appeal to consumers or brand power. Only the three best ranked or highest earning endorsers from every sport, if present, will be considered. The weighted measure will be based on the world ranking of the endorser, the number of major prizes he/she has won in a tournament or from a sport federation, how popular he is (social media followers on Instagram), and reported earnings. The weighted measure of all the endorsers will be averaged out to produce an endorser rating for the brand itself. The weighted measure is important to see the quality of the endorsers that the companies hired.

I would also like to look at total marketing costs in advertisements for the companies as I want to see if quality (high cost) or quantity (high number) is more important in endorsements to catch consumers' attention.

$$
\begin{gathered}
\text { Formula for Weighted Measure: } \\
\mathrm{WM}=\left(\mathrm{a}^{*} \mathrm{WR}+\beta^{*} \mathrm{NP}+\gamma^{*} \mathrm{P}+\delta^{*} \mathrm{E}\right) / 4 \\
\mathrm{WM}=\text { weighted measure } \\
\mathrm{WR}=\text { world ranking of the endorser } \\
\mathrm{NP}=\text { number of major prizes won in a tournament or from a sports federation } \\
\mathrm{P}=\text { popularity } \\
\mathrm{E}=\text { total earnings } \\
\text { Formula for Endorser Rating: } \\
\mathrm{ER}=\Sigma \mathrm{WM} / \mathrm{N} \\
\mathrm{ER}=\text { endorser rating } \\
\mathrm{WM}=\text { weighted measure } \\
\mathrm{N}=\text { number of endorsers }
\end{gathered}
$$


As a measure of control, I will also look at the number of stores opened as branch expansion increases brand awareness and customer base due to convenience, which can increase equipment sales. The variable acts to incorporate some other variables that may not be part of advertising and control for the changes in the equipment sales caused by these factors. It will help us understand the complexity of company revenue change, as advertising is not the only factor that affects company revenue. [See Table 6]

After all the aforementioned is found, they will be plotted on a graph and I will then run a regression that produces the best possible correlation on it to see how related the data is and assess the strength of the association between the factors and equipment sales. The sales percentage change from last year is the fixed response variable and the various experimental variables accounted for will be used on the $\mathrm{x}$-axis. Notice that the $\mathrm{x}$-axis will be time independent. The time period is used to find relevant data that can be applied for regression. All the data will be graphed, and regression will be run to see correlational values. [See Graph Template]

Comparison of the variables with revenue changes will demonstrate what variables help explain revenue changes and to what extent.

\section{RESULTS}

The top 10 sports in the world according to international viewership were found using online credible websites as it was hard to conduct data collection to measure this parameter for each sport over such a short period of time ${ }^{[\mathrm{XXII}]}$.I picked the top 5 sports from this list to form the sports that I would be looking into to find popular sports endorsers. [See Table 1]

Table1. SportsRankingand International Viewership

\begin{tabular}{|c|c|c|}
\hline Ranking & Sport Name & $\begin{array}{c}\text { International } \\
\text { Viewership }\end{array}$ \\
\hline 1 & Soccer & 4 billion \\
\hline 2 & Cricket & 2.5 billion \\
\hline 3 & Hockey & 2 billion \\
\hline 4 & Tennis & 1 billion \\
\hline 5 & Volleyball & 900 million \\
\hline 6 & Table Tennis & 875 million \\
\hline 7 & Basketball & 825 million \\
\hline 8 & Baseball & 500 million \\
\hline 9 & Rugby & 475 million \\
\hline 10 & Golf & 425 million \\
\hline
\end{tabular}

I was trying to find the top 10 richest sports in the world according to financial value. But, it was hard to measure so. So, I decided to find which sport had many athletes earning high wages to understand the bigger picture of the demand in each sport. I looked at the top 100 athletes with the highest wages and assigned them each to their sport $^{[\mathrm{XXIII}]}$. 
After this process, I ranked the sports based on who had the most athletes. Then, I picked the top 5 sports with the most athletes. [See Table 2] However, if there were any repeats from the previously selected sport, they were ignored, and I moved to the next sport in the list. These sports will also be considered when I am looking for sports athlete endorsers to compare results with.

Table2. Ranking of Sports Based on Number of Forbes Top 100 Earners in That Sport

\begin{tabular}{|c|c|c|}
\hline Ranking & Sport Name & $\begin{array}{c}\text { Number of Top 100 } \\
\text { earners (Forbes) }\end{array}$ \\
\hline 1 & Basketball & 40 \\
\hline 2 & $\begin{array}{c}\text { American } \\
\text { Football }\end{array}$ & 18 \\
\hline 3 & Baseball & 14 \\
\hline 4 & Soccer & 9 \\
\hline 5 & Golf & 5 \\
\hline 6 & Boxing & 4 \\
\hline 7 & Tennis & 4 \\
\hline 8 & Racing & 3 \\
\hline
\end{tabular}

I looked at the annual reports of the companies in my sample - Nike, Adidas, Dick's Sporting Goods, Under Armour, and Amer Sports ${ }^{[X X I V-X X V I I I]}$. I looked at their equipment sales change \% over the years 2013 to 2017. For some companies, I had to calculate the change \% by comparing current year equipment sales to last year's equipment sales. [See Table 3]

Some companies had alternate terms for equipment such as accessories or instruments. But, I was only looking at the category other than shoes and apparel.

Table3. Change in Equipment Sales [ExcludingCurrency Change] (Expressed as \%):

\begin{tabular}{|c|c|c|c|c|c|}
\hline & Nike & Adidas & $\begin{array}{c}\text { Dick's Sporting } \\
\text { Goods }\end{array}$ & Under Armour & Amer Sports \\
\hline $\mathbf{2 0 1 3}$ & $20 \%$ & $15 \%$ & $0 \%$ & $30 \%$ & $0 \%$ \\
\hline $\mathbf{2 0 1 4}$ & $4 \%$ & $-9 \%$ & $8 \%$ & $28 \%$ & $0 \%$ \\
\hline $\mathbf{2 0 1 5}$ & $1 \%$ & $-8 \%$ & $9 \%$ & $26 \%$ & $17 \%$ \\
\hline $\mathbf{2 0 1 6}$ & $-2 \%$ & $9 \%$ & $9 \%$ & $17 \%$ & $5 \%$ \\
\hline $\mathbf{2 0 1 7}$ & $-3 \%$ & $6 \%$ & $9 \%$ & $9 \%$ & $2 \%$ \\
\hline
\end{tabular}

I found the number of endorsements Adidas, Nike, and Under Armourhad currently ${ }^{[\mathrm{XXIX}-\mathrm{XXXI}]}$. The number of endorsements were measured on the $\mathrm{X}$-axis and the change 
of equipment sales were measured on the y-axis. Then, regression was used to try to find how closely the data matched to try and interpret a connection. [See Figure 1]

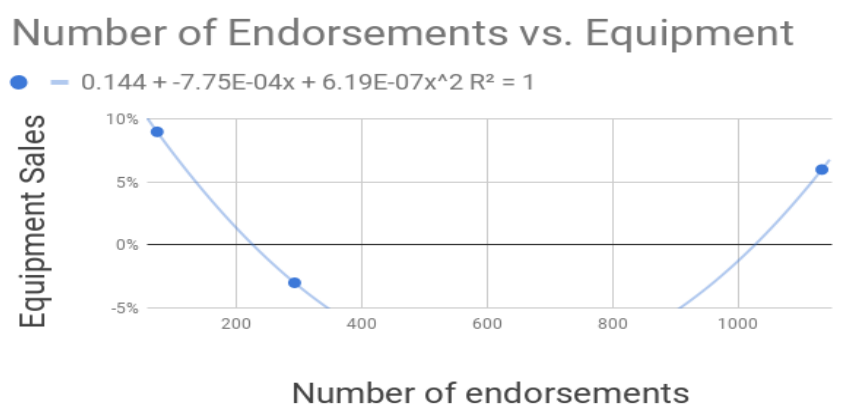

Fig 1: Relation of Equipment Sales Change with Number of Endorsements

I found the endorsement rating that each company had for 5 years based on the top 3 endorsers each company had in those years. The endorsement rating was calculated based on the formula mentioned in the methodology. The ratings were measured on the $\mathrm{x}$-axis and the change of equipment sales were measured on the y-axis. Then, regression was used to try to find how closely the data matched to try and interpret a connection. [See Figure 2]

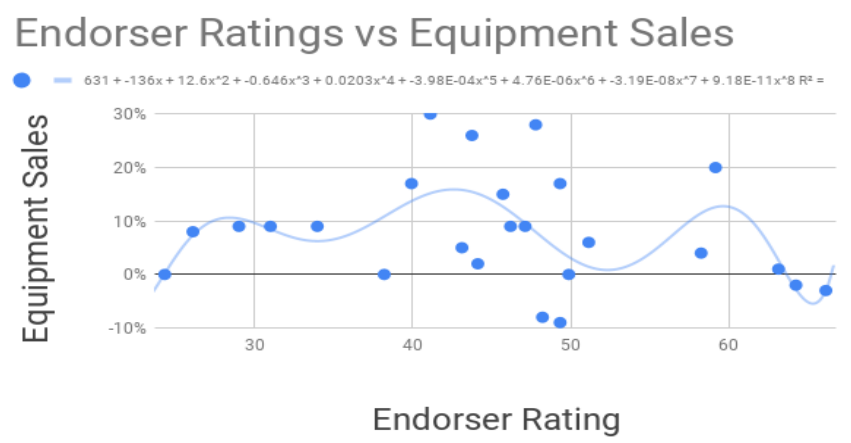

Fig 2: Relation of Equipment Sales Change with Endorser Rating

I found the total marketing costs of each company had for 5 years from the company reports ${ }^{[X X I V-X X V I I I]}$. The total marketing costs were measured on the X-axis and the change of equipment sales were measured on the y-axis. Then, regression was used to try to find how closely the data matched to try and interpret a connection. [See Figure 3]

These three connections will together be used to try and find how much athlete endorsements help increase equipment sales of a sports brand.

\section{Marketing Costs vs Equipment Sales}

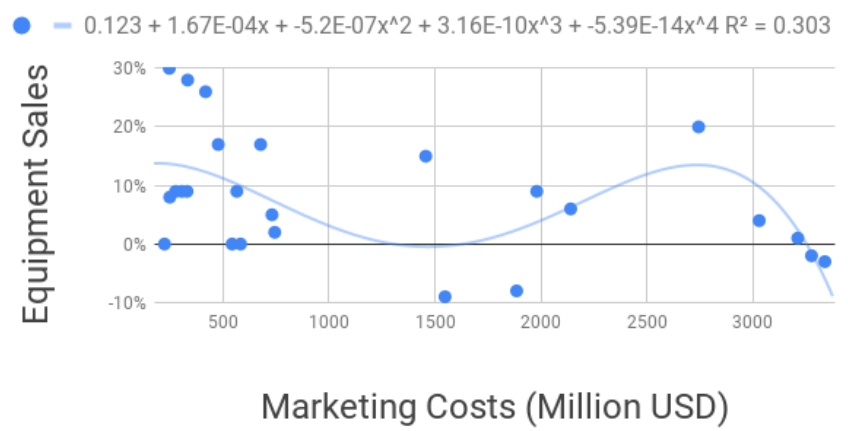

Fig 3: Relation of Equipment Sales Change with Total Marketing Costs 
Finally, as a control, I found the number of stores for each company in the 5 years based on the company reports ${ }^{[\mathrm{XXIV}-\mathrm{XXVIII}]}$. The number of stores formed the X-axis variable and the equipment sales change was made the y-axis variable. Regression was used to find a relationship between the data. [See Figure 4]

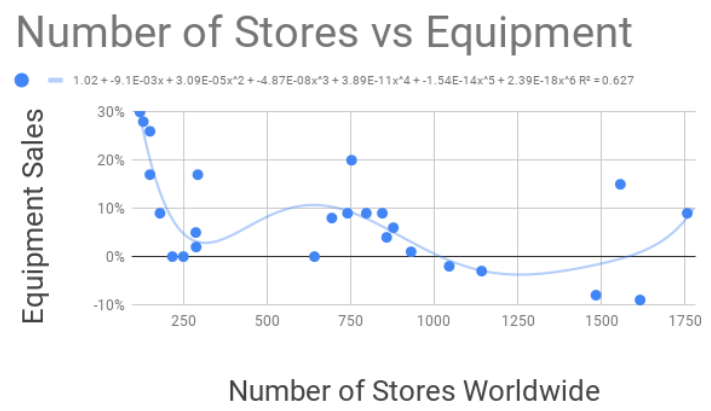

Fig 4: Relation of Equipment Sales Change with Total Marketing Costs

\section{DISCUSSION}

Initially, we must evaluate the determination of key sports that were later considered for picking athlete endorsers of the companies.

International viewership numbers were taken from sources, as it would take too long to find values by experiment. But, these values were largely reliable for estimation. Some may argue that the sources the data is received might not be credible, but the numbers are used purely for relative ranking and comparison. Hence, the results are still reliable even if the numbers are a little skewed or estimated to be slightly larger or smaller than actual values.

Later, the most commercially valuable sports were estimated based on the number of top earners each sport had. The sport each top 100 athlete endorser played was considered and each sport received numbers accordingly. The financial value of a sport was estimated based on the distribution of the richest athletes and their sports ${ }^{[\mathrm{XXII}]}$. It might not be the best estimate of a sport's value, but it suffices for finding popular sports I had to consider. It perhaps might have been better to use financial figures of popular competitions of each sport as it captures most caveats of the sport - teams, players, viewership, advertisements, etc. - but I was restricted from getting such numbers.

Now we must look at the actual equipment sales of sports equipment brands in the results that includes the impact of athlete endorsers that the brands chose for their goals. All 5 companies in the sample were analyzed for the years 2013 to 2017. 2018 was not chosen as the full year report may not have been available at the time of data collection. As the goal is to inform companies about recent emerging trends in their market, especially inadvertising, the most recent possible years were chosen.

All the data used for the correlation graphs except endorser ratings were taken directly from company reports. For equipment sales change, I consistently used figures that didn't account for changes in foreign currency. This consistency improves the validity of my data as all the figures have similar parameters. Some figures for equipment sales change of the sports brand had to be manually calculated based on the information provided. For example, the annual report of Wilson Sports featured both equipment and instruments, which had to be combined when finding equipment sales change.

The year wasn't a variable, it was simply a timeframe to collect relevant data for my research. After establishing the equipment sales changes (based on last year) for Nike, Adidas, Under Armour, Dick's Sporting Goods, and Wilson Sports from 2013 to 2017, I found values for number of endorsements, endorser ratings, total marketing costs, and 
number of stores. I created correlation graphs and found the $\mathrm{r}$, correlation coefficient, values for the relationship using Google Sheets, which is a reliable online tool for statistical purposes. I decided to use three graphs to analyze the main aspects of advertising for a sports equipment company to observe effects in equipment sales change individually. Then, I inferred and compared which aspects would be more important for companies in this market for the future.

I consistently used my definitions to find relevant data as different words described these fields in all the company reports.

\subsection{Limitations:}

No valid correlation was strong $(\mathrm{r}>0.9)$. The other correlations were slightly significant $(\mathrm{r}>0.5)$. Although Figure 1 produced a strong correlation, there were only three data points. Hence, it was invalid and essentially inconclusive. Companies themselves, however, will have better access to data about total number of endorsements. They are encouraged to try and plot all their data and try to find some relationship.

There may be a confounding variable amidst the variables chosen for the graphs. But, we can't say if this is true for certain. Examples of a confounding effect in this situation would be if the company acquired other popular companies during the period or had good share prices consistently in addition to making good endorser choices. As the area of endorsements and endorsers for sports equipment brands is the main focus of this research, attention should not be diverted to these other factors.

\subsection{Implications:}

The endorser rating of the companies in ten popular sports was calculated based on the three best endorsers, which is a simplification of the total impact endorsers have. Yet, the most well-known endorsers contribute to success much more than others. As only those endorsers whose ratings could be compiled were included in the endorser rating calculation for the sports brand, the results might be slightly affected. It is likely that the data is slightly skewed, but it was across all sports equipment brands focused on. A correlation graph was made using the gathered data and we obtained a barely significant correlation. The graph generated a wavy function, which peaked at all positive values. It suggests good endorser ratings benefit equipment sales in ranges. The difference between two endorser ratings in the same range will be similar. This finding isn't surprising as sports equipment brands compete with each other to obtain influential athlete endorsers. Having better athlete endorsers can now be explained statistically as a wise choice for brands to make in order to increase equipment sales.

Now, for the total marketing costs. The marketing costs were also devoid of changes in foreign currency for consistency. A correlation graph was made. The correlation resulted in a slightly more significant graph. The graph fluctuates and stays positive until it dips right at the end where marketing costs have exceeded the marginal benefit they gave in equipment sales. It helps companies see that they cannot overshoot their budget as it is likely going to be harmful. Hence, they must set their marketing costs at a minimalistic budget (first peak) or good enough target (second peak).

The correlation graph for number of stores was a negative asymptotic function. The benefit was highest when the number of stores were the lowest. This can be explained by the fact that lesser supply results in higher demand and sales growth. After that point, the graph was largely an asymptote with a little bump in the middle. Companies must thus realize that every additional store will contribute even lesser. So, the store should be installed only if there is confidence in its profitability. 
Polynomial regression was chosen for all the graphs because it resulted in strong correlations and allowed for the highest flexibility in shape. Polynomial regression also gave more insight on particular areas where there is consistent growth in brand equipment sales and certain areas where the rise in equipment sales levels off. Polynomial regression portrayed a picture of a smooth curve which fits realistic situations better than linear regression.

This research dispels the notion that simply more endorsements or better endorsers can guarantee increased equipment sales. Additionally, it proposes that there may be a good range for the number of endorsements and number of stores that can increase the likelihood of increasing equipment sales change.

\section{CONCLUSION}

Endorser rating and total marketing costs together proved to be more influential for better equipment sales. Number of endorsements had a negligible effect on the equipment sales. In fact, number of endorsements proved to be harmful outside a conducive range for advertising.

This study promotes more analysis in this sector to understand endorsements better. Future research can focus on what effects unconventional forms of advertising, such as ingame ads and word of mouth publicity, can have on the market ${ }^{[\mathrm{VI}]}$. In terms of equipment sales change, smaller companies such as Dick's Sporting Goods and Under Armour have seen more growth than giants such as Nike and Adidas. Future research can also attempt to find a better correlation between endorsement influence and equipment sales change than the one found in this research effort. Other researchers may choose to analyze stock prices or net profit and then compare it with their endorsers or other marketing aspects.

\section{References}

I. R. Gunston, Play ball!,Futurist, Vol.39(1), pp. 31-36, 2005. http://sks.sirs.com/webapp/article?artno=0000208054\&type=ART

II. L.Aureliano-Silva, E. L.Lopes, O. B.De Lamonica Freire, and D.da Silva, The brand's effect on the evaluation of advertising endorsed by celebrities: an experimental study. Brazilian Business Review, Vol.12(4), pp. 57+, 2015. http://link.galegroup.com/apps/doc/A424598188/GPS?u=j043905006\&sid=GPS\&xid=f62caa $\underline{45}$

III. M.Peyser, T.Ehrenfeld, and A.Davis, He scored as much for corporate America as he did for the Bulls. Sports marketing will never be the same,Newsweek, Vol.133(4), pp. 54,January 25, 1999.

http://link.galegroup.com/apps/doc/A53612344/OVIC? $\mathrm{u}=\mathrm{j} 043905006 \&$ sid=OVIC\&xid=6f4c $\underline{27 \mathrm{ef}}$

IV. S. M.Almeida, A. J.D'Souza,and T.Dolma, Brand Loyalty of Students towards Sports Accessories,Asian Journal of Management, 2018. http://link.galegroup.com/apps/doc/A534622326/GPS?u=j043905006\&sid=GPS\&xid=193ca5 $\underline{\mathrm{fc}}$

$\mathrm{V}$. The NBA will be the first major North American sports league to allow corporate logos on team jerseys. Let's stop the trend there,Maclean's, Vol.129(17), pp. 5,May 2, 2016.http://link.galegroup.com/apps/doc/A451634776/OVIC?u=j043905006\&sid=OVIC\&xi $\mathrm{d}=6233956 \mathrm{c}$

VI. P.Kraftand J. W. Lee, Protecting the house of Under Armour. Sport Marketing Quarterly, Vol. 18(2), pp. $112+$, 2009.http://link.galegroup.com/apps/doc/A201712741/GPS?u=j043905006\&sid=GPS\&xid=a $\underline{\mathrm{f} 4 \mathrm{acc} 55}$ 
VII. D. F.GerritsenandS. van Rheenen, The value of winning: endorsement returns in individual sports,Marketing Letters, Vol.28(3), pp. 371+, 2017.

http://dx.doi.org/10.1007/s11002-017-9422-9

VIII. Why your brain can't resist a celebrity endorsement,USA Today, p. 5, November 6, 2017.http://link.galegroup.com/apps/doc/A513756102/OVIC?u=j043905006\&sid=OVIC\&xi $\mathrm{d}=04 \mathrm{f} 22 \mathrm{fe} 0$

IX. G. H.Popescu, "The economic value of celebrity endorsements: a literature review," Economics, Management, and Financial Markets, Vol.9(4), pp. 119+, 2014.http://link.galegroup.com/apps/doc/A399572241/GPS?u=j043905006\&sid=GPS\&xid=1 $19618 \mathrm{bb}$

X. G.Y.Koo, B. J.Ruihley,and S. W.Dittmore, Impact of perceived on-field performance on sport celebrity source credibility,Sport Marketing Quarterly, Vol.21(3), pp. 147+,2012. http://link.galegroup.com/apps/doc/A323259163/GPS?u=j043905006\&sid=GPS\&xid=74848 a $7 \mathrm{c}$

XI. C.C.Yu, Athlete endorsement in the international sports industry: a case study of David Beckham. International Journal of Sports Marketing \& Sponsorship, Vol.6(3), pp. 189+, April 2005. http://ink.galegroup.com/apps/doc/A133136109/GPS? $=$ j043905006\&sid=GPS\&xid=54e71c d4

XII. Sports,In Encyclopaedia

Britannica,2018.https://school.eb.com/levels/high/article/sports/108486\#253580.toc

XIII.B.Horovitz,Wishing on a star: Celebrity endorsements draw big bucks—but,Los Angeles Times, 7 November, 1993.

http://discoverer.prod.sirs.com/discoweb/disco/do/article?urn=urn\%3Asirs\%3AUS\%3BARTI CLE\%3BART\%3B0000024471

XIV. J. Kirby, Fame doesn't sell: new research suggests celebrity endorsements are losing their appeal. Maclean's, Vol.120(17), pp. 32,May 7,

2007.http://link.galegroup.com/apps/doc/A163153844/OVIC?u=j043905006\&sid=OVIC\&xi $\mathrm{d}=\mathrm{b} 9 \mathrm{fdfb} 01$

XV. S. K.Koernig, and T. C.Boyd, To catch a tiger or let him go: the match-up effect and athlete endorsers for sport and non-sport brands,Sport Marketing Quarterly, Vol.18(1), pp. 25+, 2009http://link.galegroup.com/apps/doc/A200185610/ITOF?u=j043905006\&sid=ITOF\&xid= $2 \mathrm{~b} 4 \mathrm{e} 219 \mathrm{c}$

XVI. K.Belson, and R.Sandomir, Insuring endorsements against athletes' scandals. New York Times, pp. D2(L). February 1, 2010.

http://link.galegroup.com/apps/doc/A217927652/OVIC?u=j043905006\&sid=OVIC\&xid=be7 79c64

XVII. Y.Upadhyay,and S. K. Singh,. When Sports Celebrity Doesn'tPerfrom: How Consumers React to Celebrity Endorsement?,January 1, 2010. https://journals.sagepub.com/doi/abs/10.1177/097226291001400107

XVIII. K. Y.Chung,T. P. Derdenger,andK. Srinivasan, Economic Value of Celebrity Endorsements: Tiger Woods' Impact on Sales of Nike Golf Balls, Marketing Science, Vol.32(2), pp.271293, March 1, 2013. https://doi.org/10.1287/mksc. 1120.0760

XIX. A.Elberse, andJ. Verleun, The Economic Value of Celebrity Endorsements,Journal of Advertising Research, Vol.52(2), pp. 149-165,2012. http://dx.doi.org/10.2501/JAR-52-2-149-165

XX. J. H.Martin, Is the athlete's sport important when picking an athlete to endorse a nonsportproduct?,Journal of Consumer Marketing, Vol.13(6), pp.28+. 1996.http://link.galegroup.com/apps/doc/A19099789/ITOF? $\mathrm{u}=$ j043905006\&sid=ITOF\&xid= $\underline{42 \mathrm{da} 8 \mathrm{c} 0 \mathrm{a}}$

XXI. M.Dupee, P.Werthner,and T.Forneris, A Preliminary Study on the Relationship Between Athletes' Ability to Self-Regulate and World Ranking,Biofeedback, Vol.43(2), pp. 5763,2015.http://dx.doi.org/10.5298/1081-5937-43.2.01

XXII. B. E. Sawe, The Most Popular Sports in the World,September 16, 2016. 
https://www.worldatlas.com/articles/what-are-the-most-popular-sports-in-the-world.html

XXIII. Forbes,“The World's Highest Paid Athletes 2018,” Forbes Magazine, 2018.www.forbes.com/athletes/\#7b4ea64e55ae.

XXIV. Adidas, Financial Publications,2018. https://www.adidas-group.com/en/investors/financial-reports/

XXV. Amer Sports, Financial Reviews, 2018. https://www.amersports.com/investors/reports-and-presentations/financial-reviews/

XXVI. Dick's Sporting Goods Inc., 2018. http://www.annualreports.com/Company/dicks-sporting-goods-inc

XXVII. Nike Sports, Annual Reports, 2018. https://investors.nike.com/investors/news-events-and-reports/?toggle=reports

XXVIIIUnder ArmourInc, 2018. http://www.annualreports.com/Company/under-armour-inc

XXIX.List of Adidas sponsorships,2019. https://en.wikipedia.org/wiki/List_of_Adidas_sponsorships

XXX.List of Nike sponsorships, 2019. https://en.wikipedia.org/wiki/List of Nike sponsorships

XXXI.List of Under Armour sponsorships, 2019. https://en.wikipedia.org/wiki/List_of_Under_Armour_sponsorships 